\title{
Impact of Heat Stress on Selected Parameters of Robotic Milking
}

\author{
Roman Gálik ${ }^{1}$, Gabriel Lüttmerding ${ }^{1, * \mathbb{D}}$, Štefan Bod'o ${ }^{1}$, Ivana Knížková ${ }^{2}$ and Petr Kunc ${ }^{2}$ \\ 1 Institute of Agricultural Engineering, Transport and Bioenergetics, Faculty of Engineering, \\ Slovak University of Agriculture in Nitra, Tr. A. Hlinku 2, 94976 Nitra, Slovakia; \\ roman.galik@uniag.sk (R.G.); stefan.bodo@uniag.sk (Š.B.) \\ 2 Livestock Technology and Management, Institute of Animal Science, Přátelství 815, Uhříněves, \\ 10400 Praha, Czech Republic; knizkova.ivana@vuzv.cz (I.K.); kunc.petr@vuzv.cz (P.K.) \\ * Correspondence: xluttmerding@uniag.sk
}

Citation: Gálik, R.; Lüttmerding, G.; Bod'o, Š.; Knížková, I.; Kunc, P. Impact of Heat Stress on Selected Parameters of Robotic Milking. Animals 2021, 11, 3114. https:// doi.org/10.3390/ani11113114

Academic Editor: Agostino Sevi

Received: 22 September 2021

Accepted: 27 October 2021

Published: 30 October 2021

Publisher's Note: MDPI stays neutral with regard to jurisdictional claims in published maps and institutional affiliations.

Copyright: (c) 2021 by the authors. Licensee MDPI, Basel, Switzerland. This article is an open access article distributed under the terms and conditions of the Creative Commons Attribution (CC BY) license (https:// creativecommons.org/licenses/by/ $4.0 /)$.
Simple Summary: The aim of this study was to verify the effect of temperature stress on dairy cows milked in an automatic milking system in the temperate climate of central Europe. The study showed that there was not a decrease in the daily milk yield per milking if the temperature-humidity index value was lower than 68 . This was accomplished with the dairy cows having an average daily milk yield of $29 \mathrm{~kg}$ to $31 \mathrm{~kg}$. A decrease of the daily milk yield per cow was recorded if the temperature-humidity index value was greater than 72. A higher average milk speed, as well as a higher maximum milk speed, may occur with a temperature-humidity index value higher than 68.

\begin{abstract}
The values of the temperature-humidity index and its influence on the performance parameters of dairy cows were monitored on four farms located in the southern part of the central Slovakia during a period of three years. The observed parameters included: the milk yield per cow per day, average milk speed and maximum milk speed. The thermal-humidity index was calculated based on a formula. The individual periods were divided according to the achieved THI. The results of dairy cows with a milk yield of $29 \mathrm{~kg}$ to $31 \mathrm{~kg}$ show that there is not a decrease in the milk yield per milking if the THI value is lower than 68. It was also found that there was a decrease in the milk yield per dairy cow in the robotic milking parlor for a THI value greater than 72 . The influence of a THI value higher than 68 in these dairy cows results in a higher average milk speed, as well as a higher maximum milk speed. These two parameters are not yet in the main area of research interest. This study enriches the area with new knowledge, according to which dairy cows can show thermal stress by increasing the milk speed as well as the maximum milk speed.
\end{abstract}

Keywords: temperature-humidity index; automatic milking system; dairy cow; average milk speed; maximum milk speed

\section{Introduction}

Automatic milking systems (AMS) have been used in dairy farms more and more over the past two decades. The system gives an opportunity for cattle to decide when to be milked [1]. The other advantages include the reduction of the workload for the staff on the dairy farm, along with the possibility of milking more than twice a day without higher labor costs. However, the AMS does not only include its own robotic milking also represents a completely new management on dairy farms [2-4].

However, the expected positive effects of this type of milking may be disturbed by inappropriate microclimatic and macroclimatic conditions $[5,6]$. In particular, heat stress does significantly affect the welfare of cattle with all its negative effects, such as a reduced milk yield, reduced feed intake, increased water consumption, changes in the milk composition, impaired reproductive performance, etc. [7-11].

The Thermal Humidity Index (THI) is frequently used to describe the heat load. It is a very important indicator of the quality of the barn environment. It does combine the 
effect of the air temperature and the relative humidity [9,12-16]. The THI model does not take into account other environmental factors, such as the air velocity or the solar radiation intensity; the $\mathrm{THI}$ is still considered to be an excellent indicator of stressful climatic conditions $[9,14]$.

A high THI value does negatively affect the milk yield of dairy cows $[9,12,14,17]$. A value of THI above 72 is considered to be a critical value [6]. A decline in the milk yield was also noted two days before reaching the limit values of THI $[18,19]$. A decrease in the milk yield was found at a four-day interval when the THI value was above 72 [20]. The daily milk production began to decline between THI values of 65 to 76 [21]. A THI value of 68 does adversely affect the dairy cow's organism [22,23]. The limit for dairy cows producing more than $35 \mathrm{~kg}$ of milk per day is a THI value of 68 [24].

The aim of this study was to analyze the impact of THI on selected parameters of robotic milking.

\section{Materials and Methods}

\subsection{Farms and Animals}

The study was carried out on four dairy farms (A, B, C, D) with the AMS in the Slovak Republic. The herds comprised lactating dairy cows of the Holstein breed after the first calving, as well as older ones. The dairy cows were kept in a loose housing with cubicle beds \& bedding with free access to all milking robots and were fed the same total mixed ration. Two types of the AMS were used on these farms-the Lely Astronaut A3 and the Lely Astronaut A4 (Lely, Maassluis, The Netherlands). Table 1 shows the details of these farms.

Table 1. Description of the dairy farms.

\begin{tabular}{ccccc}
\hline Farm & $\begin{array}{c}\text { Type of the Automatic } \\
\text { Milking System }\end{array}$ & $\begin{array}{c}\text { Number of the Automatic } \\
\text { Milking System on the Farm }\end{array}$ & $\begin{array}{c}\text { Number of } \\
\text { Dairy Cows }\end{array}$ & $\begin{array}{c}\text { Average Annual } \\
\text { Performance per Dairy Cow (kg) }\end{array}$ \\
\hline A & Lely Astronaut A3 & 1 & 58 & 6517.00 \\
B & Lely Astronaut A4 & 4 & 288 & 8717.56 \\
C & Lely Astronaut A4 & 4 & 295 & 7500.00 \\
D & Lely Astronaut A4 & 4 & 303 & 8710.25 \\
\hline
\end{tabular}

\subsection{Data Collection}

The study lasted between 2015, 2016 and 2017. The monitored parameters were: the milk yield per cow per day ( $\mathrm{kg} /$ day), average milk speed $(\mathrm{kg} / \mathrm{min})$ and maximum milk speed $(\mathrm{kg} / \mathrm{min})$. These data were obtained from the farm reports (AMS reports) of the selected farms.

Next, the air temperature and the relative humidity were continuously measured throughout the study to calculate the THI. The air temperature and its relative humidity were recorded by Comet COMMETER D3120 recorders (COMET SYSTEM, s.r.o., Roznov pod Radhostem, the Czech Republic). These measuring devices were placed in the barn in such a way that the cows did not have access to these devices.

The THI was calculated based on the values of the air temperature and the relative humidity. The following formula was used [25]:

$$
\mathrm{THI}=\mathrm{Tdb}-\left[0.55-\left(0.55 \times \frac{\mathrm{RH}}{100}\right)\right] \times(\mathrm{Tdb}-58)
$$

where:

$\mathrm{Tdb}=$ air temperature, ${ }^{\circ} \mathrm{F} ;$

$\mathrm{RH}=$ relative humidity, \%.

Individual THI values were classified into the following zones $[9,18]$, listed in Table 2. 
Table 2. Overview of the zones calculated according to the temperature-humidity index.

\begin{tabular}{ccc}
\hline Number of the Zone & Range of the Values in the Zone & Classification of the Zone \\
\hline 1 & $64-67$ & stress-free zone \\
2 & $68-71$ & very mild stress zone \\
3 & $72-79$ & moderate stress zone \\
4 & $80-89$ & severe stress zone \\
5 & $90-98$ & extreme stress zone \\
6 & $99-104$ & death zone \\
\hline
\end{tabular}

We monitored the data from the three days before reaching the second zone of the THI (68-71), followed by the data from the days when the THI was above 68 and the data from the one day after the THI fell below 68 .

\subsection{Data Analysis}

In the evaluation we only included the data from the summer period-June, July and August - in each monitored year. The farms were evaluated individually. The data from the three days before reaching the second zone of the THI (68-71) were monitored, followed by the data from the days when the THI was above 68 and the data from the one day after the THI fell below 68 .

Table 3 lists the details of the zones of evaluation we used to describe the graphs.

Table 3. Zones of evaluation.

\begin{tabular}{cc}
\hline Number of the Zone & Description of the Zone \\
\hline 1. & 3 days before the zone of a very mild stress \\
2. & very mild stress $(68-71)$ \\
3. & moderate stress zone $(72-79)$ \\
4. & the day after the decrease of THI under 68 \\
\hline
\end{tabular}

The evaluation included the following effects: the effect of the THI on the milk yield per cow per day $(\mathrm{kg} /$ day $)$, the effect of the THI on the average milk speed $(\mathrm{kg} / \mathrm{min})$ and the effect of the THI on the maximum milk speed $(\mathrm{kg} / \mathrm{min})$.

\subsection{Statistical Analysis}

The obtained data were initially processed in Microsoft Office Excel (Microsoft, Redmond, the United States of America). The program Statistica 7 CZ (TIBCO, Palo Alto, UNITED STATES OF AMERICA) was used for the statistical evaluation of the results and for creating the graphs. The data were expressed as means $\pm \mathrm{SD}$ (standard deviation). A one-way ANOVA and the Tukey's HSD post hoc test were utilized. A 95\% confidence interval was selected $(p<0.05)$.

\section{Results and Discussion}

Table 4 shows the most number of days with a THI value greater than 68 . They were recorded in the first year and measured on all four farms. The most days with a THI of 72-79 were recorded on farm A. The most days with a THI value greater than 68 were recorded on farm $\mathrm{C}$ in the first year. In total, the most days with a THI value greater than 68 were recorded on farm A during the total 125 days in the summer period.

Table 5 shows the results of the descriptive statistics of the data from all four farms. There was only one milking robot on farm A, and on farms B, C, and D there were four milking robots. Only the data from June, July and August during the three years were statistically processed. Using these data, the impact of THI on individual parameters was monitored and statistically evaluated. 
Table 4. Number of days with the highest temperature-humidity index value.

\begin{tabular}{|c|c|c|c|}
\hline Farm & Year & $\begin{array}{l}\text { Days with Temperature-Humidity Index Value } \\
\text { in Range of } 68-71\end{array}$ & $\begin{array}{c}\text { Days with Temperature-Humidity Index Value } \\
\text { in Range of } 72-79\end{array}$ \\
\hline \multirow{3}{*}{ A } & 1 & 22 & 31 \\
\hline & 2 & 19 & 12 \\
\hline & 3 & 25 & 16 \\
\hline \multirow{3}{*}{ B } & 1 & 26 & 12 \\
\hline & 2 & 17 & 2 \\
\hline & 3 & 16 & 7 \\
\hline \multirow{2}{*}{$\mathrm{C}$} & 1 & 26 & 29 \\
\hline & 2 & 18 & 12 \\
\hline \multirow{3}{*}{$\mathrm{D}$} & 1 & 26 & 4 \\
\hline & 2 & 12 & 2 \\
\hline & 3 & 10 & 3 \\
\hline
\end{tabular}

Table 5. Results of the descriptive statistics of all four farms.

\begin{tabular}{|c|c|c|c|c|c|}
\hline Farm & Parameter & Average & Minimum & Maximum & Standard Deviation \\
\hline \multirow{4}{*}{ A } & Milk yield per cow per day (kg) & 19.09 & 15.3 & 24.6 & 1.61 \\
\hline & Average milk speed $(\mathrm{kg} / \mathrm{min})$ & 1.72 & 1.4 & 2.1 & 0.18 \\
\hline & Maximum milk speed $(\mathrm{kg} / \mathrm{min})$ & 2.81 & 2.6 & 3.2 & 0.13 \\
\hline & THI & 70.11 & 59.55 & 78.29 & 3.9 \\
\hline \multirow{4}{*}{$\mathrm{B}$} & Milk yield per cow per day (kg) & 28.96 & 18.8 & 38.3 & 3.23 \\
\hline & Average milk speed $(\mathrm{kg} / \mathrm{min})$ & 2.81 & 2.3 & 3.3 & 0.17 \\
\hline & Maximum milk speed $(\mathrm{kg} / \mathrm{min})$ & 3.93 & 3.3 & 4.5 & 0.21 \\
\hline & THI & 68.04 & 58.74 & 75.84 & 3.58 \\
\hline \multirow{4}{*}{$\mathrm{C}$} & Milk yield per cow per day (kg) & 23.34 & 13.3 & 27.2 & 1.65 \\
\hline & Average milk speed $(\mathrm{kg} / \mathrm{min})$ & 2.3 & 2.0 & 2.6 & 0.1 \\
\hline & Maximum milk speed $(\mathrm{kg} / \mathrm{min})$ & 3.3 & 3.0 & 3.8 & 0.14 \\
\hline & THI & 69.6 & 59.31 & 76.85 & 3.95 \\
\hline \multirow{4}{*}{$\mathrm{D}$} & Milk yield per cow per day (kg) & 31.27 & 24.3 & 38.3 & 2.46 \\
\hline & Average milk speed (kg/min) & 2.93 & 2.3 & 3.3 & 0.16 \\
\hline & Maximum milk speed $(\mathrm{kg} / \mathrm{min})$ & 4.13 & 3.4 & 4.6 & 0.23 \\
\hline & THI & 67.55 & 59.83 & 74.86 & 3.36 \\
\hline
\end{tabular}

The highest average value of the milk yield per cow per day was found on farm $D$, with $31.27 \mathrm{~kg}$. The highest average value of the milk speed was found on farm D, with $2.93 \mathrm{~kg} / \mathrm{min}$. The highest average value of the maximum milk speed was found on farm $\mathrm{D}$, with $4.13 \mathrm{~kg} / \mathrm{min}$. The highest value of the THI was found on farm A, with a THI value of 70.11 .

Figure 1 shows a decrease in the daily milk yield, specifically on farm B. With a THI value greater than 72 (3rd zone of evaluation), a statistically significant $(p<0.05)$ decrease of $0.40 \mathrm{~kg}$ and $0.49 \mathrm{~kg}$ was found in the milk yield, respectively, when compared to the 1st or 2nd zone of evaluation. After the return of a THI value below 68 (4th zone of evaluation), there was a statistically insignificant increase in the daily milk yield (from $12.05 \mathrm{~kg}$ to $12.23 \mathrm{~kg})$. 


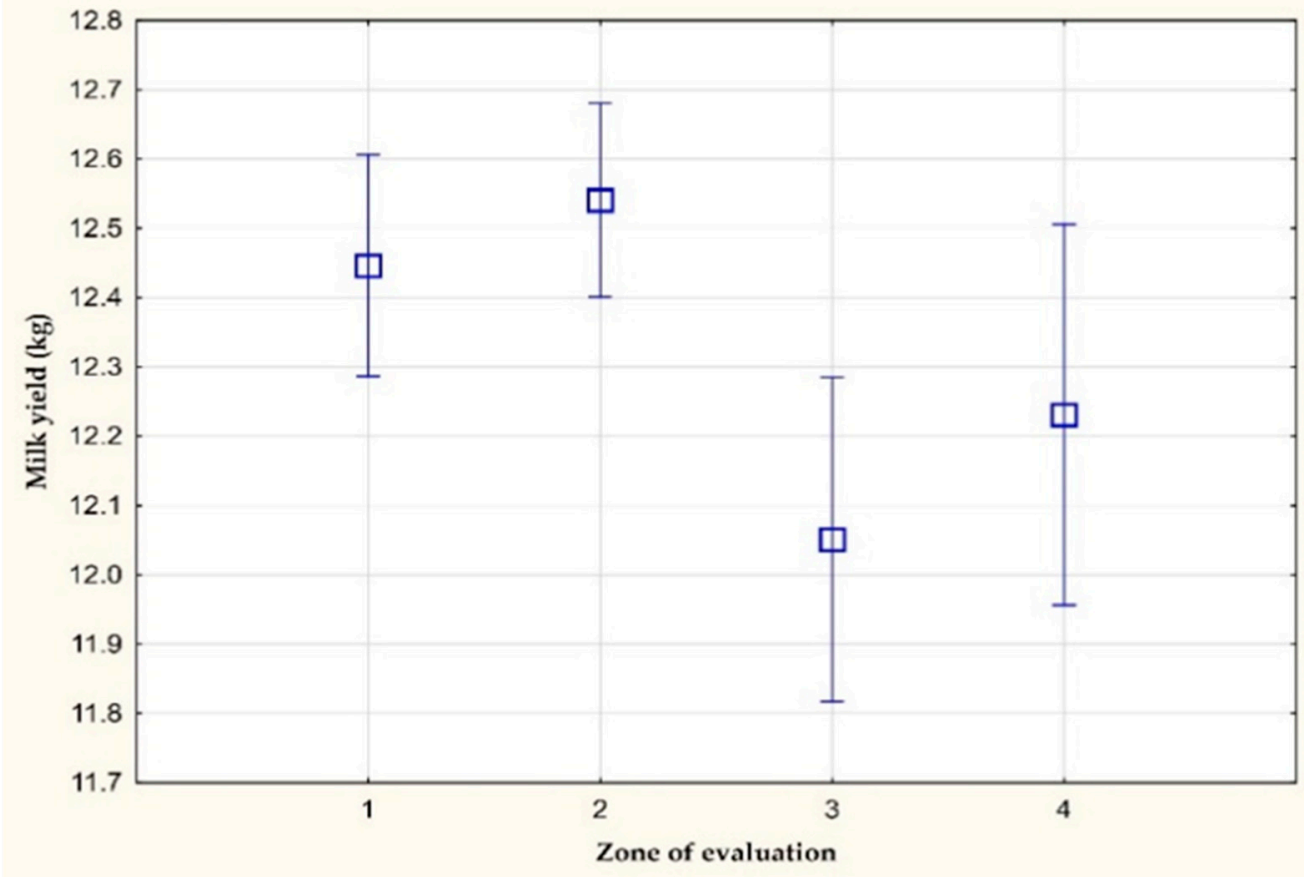

Figure 1. The amount of milk yield per milking $(\mathrm{kg})$ on farm B.

Figure 2 shows the average values of the daily milk yield on farm D. A statistically significant difference $(p<0.05)$ in the milk yield was recorded between the 1st and 3rd zone of evaluation. The decrease in the milk yield was $0.44 \mathrm{~kg} /$ day. The value of the daily milk yield in the 4th zone of evaluation did not reach the original levels, which were from before the effect of heat stress. This result is in agreement with the research of $[9,12,14,17]$. The authors reported that a high THI value negatively affected the milk production of dairy cows. The daily milk yield did not return to its original level from before the effect of heat stress, which was related to the physiological reactions of cattle to heat stress [26,27].

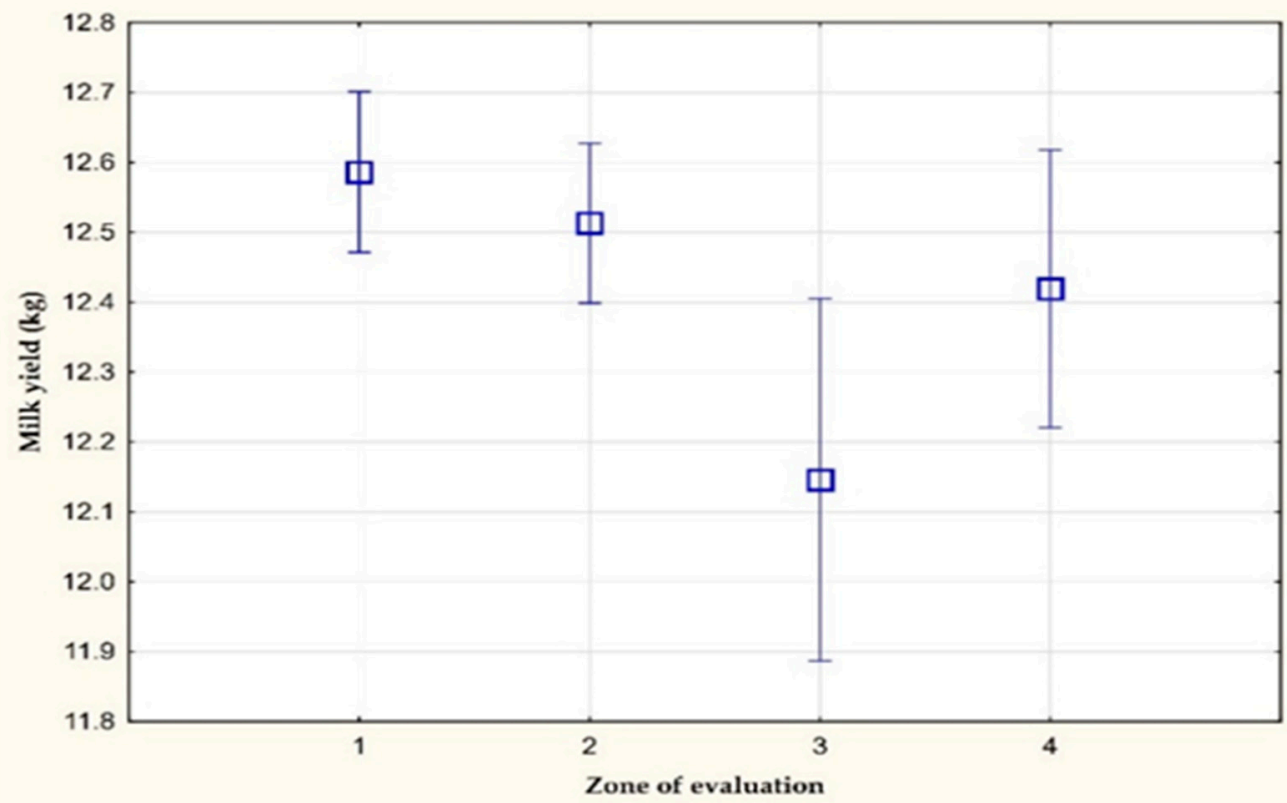

Figure 2. The amount of milk yield per milking $(\mathrm{kg})$ on farm D. 
Figures 3 and 4 show the average values of the average milk speed and maximum milk speed on farm C. A statistically significant difference $(p<0.05)$ was observed in the average milk speed between the values of the 1 st and $3 \mathrm{rd}$ zone of evaluation. The average milk speed in the stress-free zone (1st zone of evaluation) was $0.04 \mathrm{~kg} / \mathrm{min}$ lower than in the zone with a THI value greater than 72 (3rd zone of evaluation). The other differences were not statistically significant. However, a statistically significant difference $(p<0.05)$ in the mean values of the maximum milk speed was found between the values of the 1st and 3rd zone of evaluation $(0.06 \mathrm{~kg} / \mathrm{min})$.

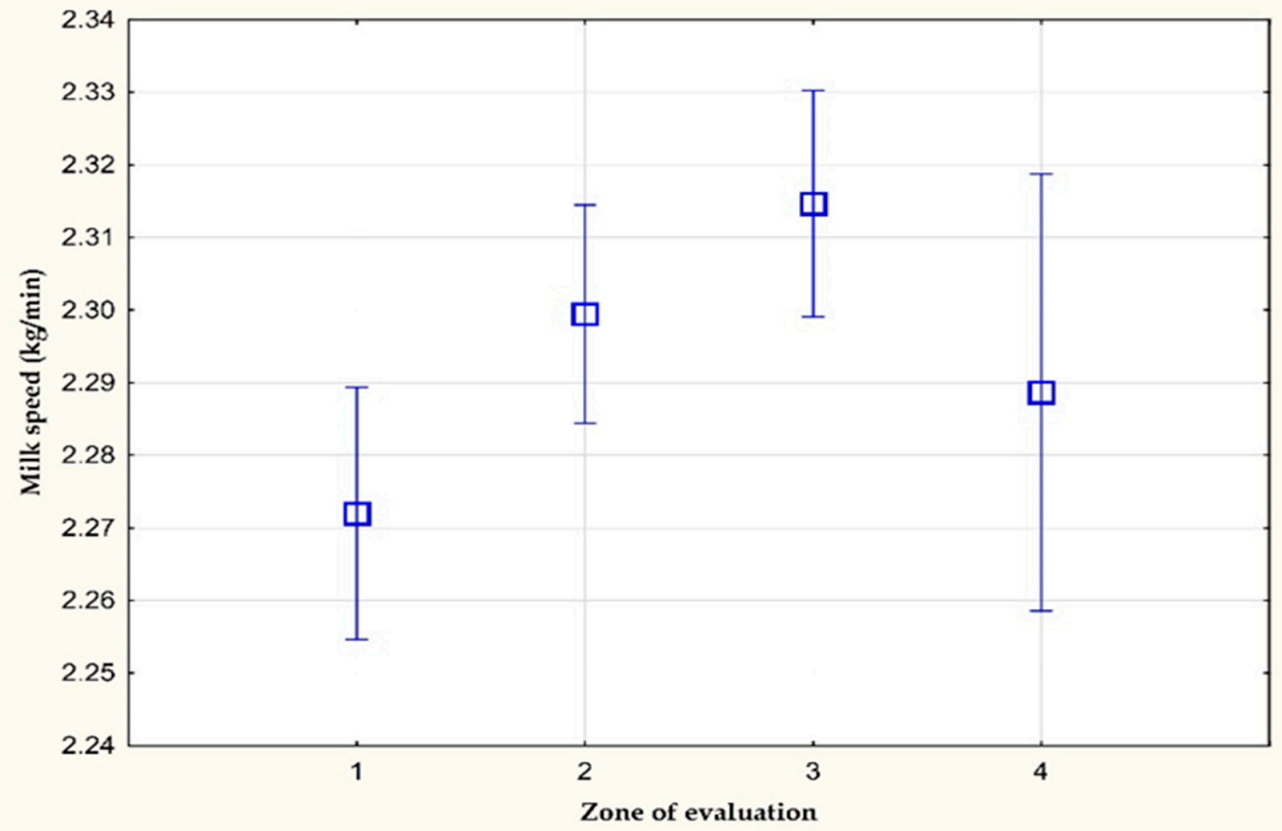

Figure 3. The average milk speed $(\mathrm{kg} / \mathrm{min})$ on farm $\mathrm{C}$.

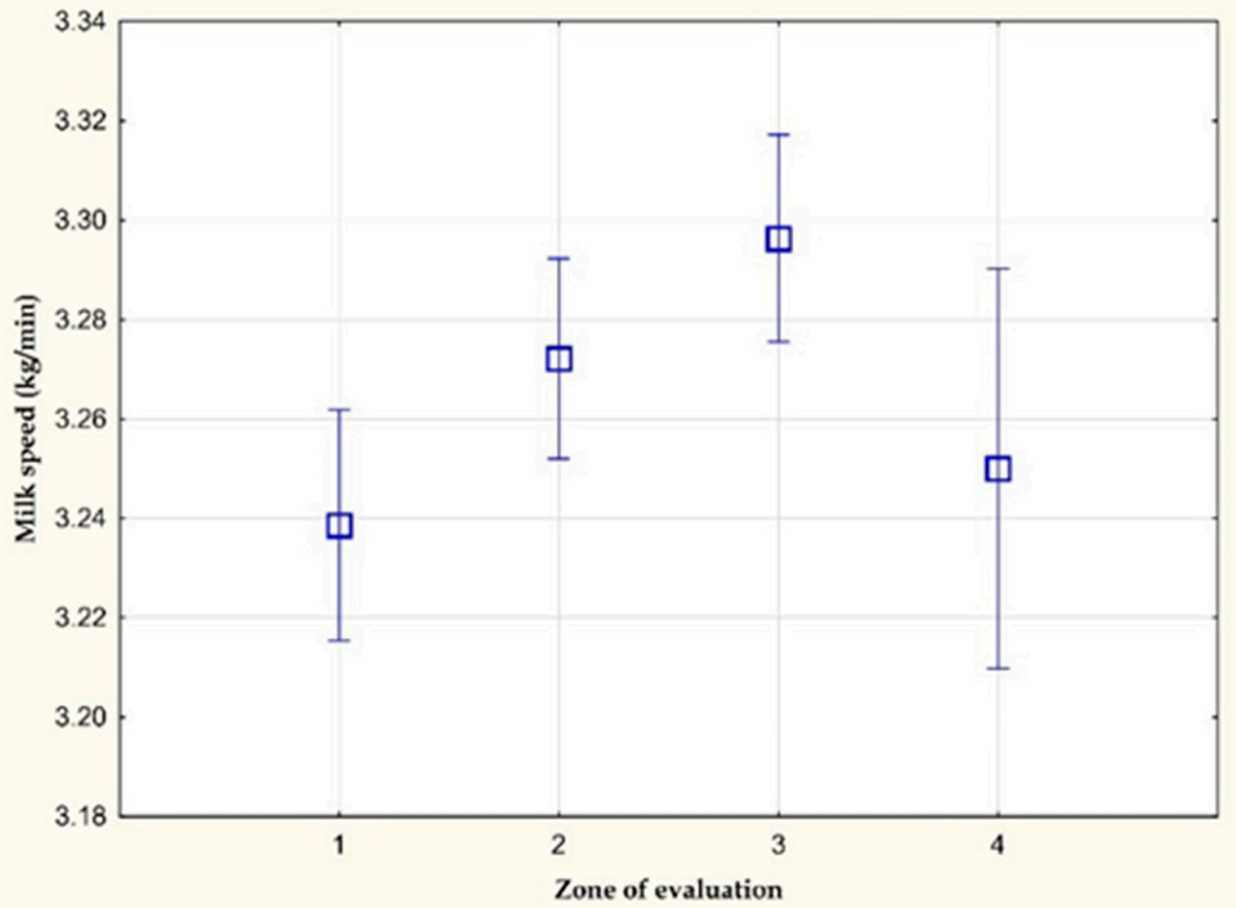

Figure 4. The maximum milk speed $(\mathrm{kg} / \mathrm{min})$ on farm $\mathrm{C}$. 
Figures 5 and 6 show the average values of the average milk speed and maximum milk speed on farm D. In the case of this farm, a statistically significant difference was found between the values of the 1st and 2nd zone of evaluation $(0.08 \mathrm{~kg} / \mathrm{min})$, and also between the values of the 1st and $3 \mathrm{rd}$ zone of evaluation $(0.11 \mathrm{~kg} / \mathrm{min})$. The other differences were not statistically significant. However, a statistically significant difference $(p<0.05)$ in the mean values of the maximum milk speed was found between the values of the 1st and 2nd zone of evaluation $(0.13 \mathrm{~kg} / \mathrm{min})$ and between the 1st and 3rd zone of evaluation $(0.11 \mathrm{~kg} / \mathrm{min})$. The other differences were not statistically significant.

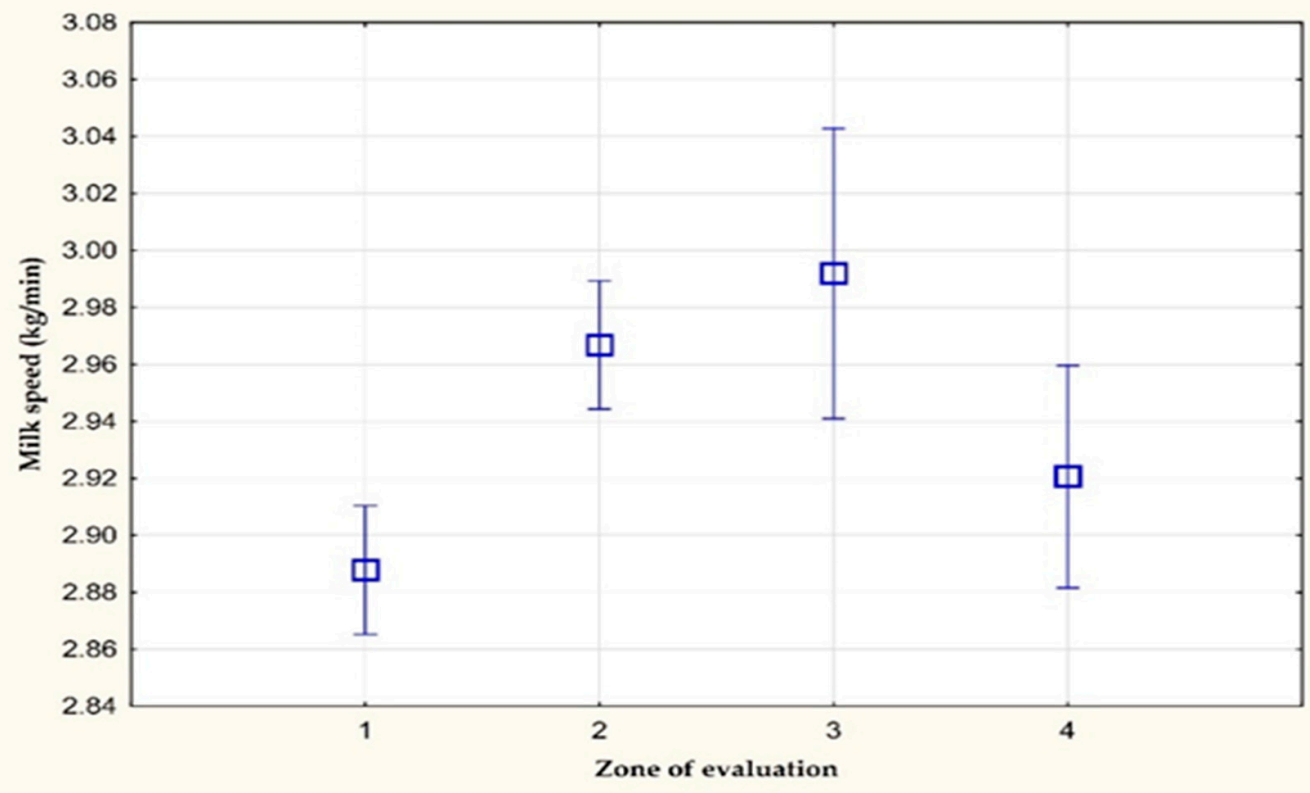

Figure 5. The average milk speed $(\mathrm{kg} / \mathrm{min})$ on farm $\mathrm{D}$.

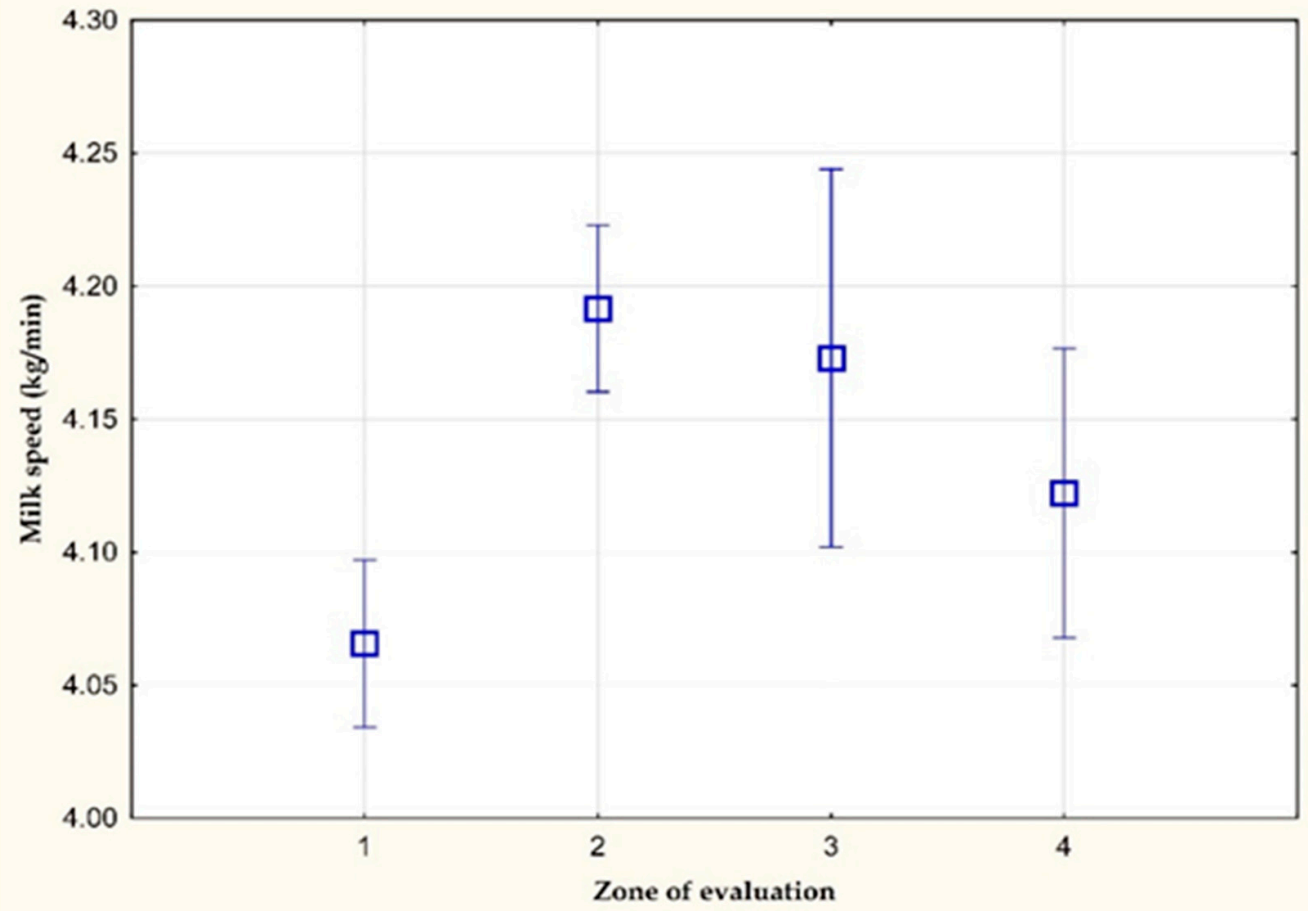

Figure 6. The maximum milk speed $(\mathrm{kg} / \mathrm{min})$ on farm D. 
These results show that when a dairy cow is under heat stress, the animal tries to eject milk more quickly [26]. This is probably due to the fact that the cow is trying to get rid of the accumulated heat in the form of milk. This is in agreement with the claims of $[19,28-31]$, who state that the metabolic heat output increases with the amount of milk, and so that the cows try to get rid of this metabolic heat. The genetic selection for the milk speed is feasible, and the existence of a correlation structure between the milk speed and milk yield, however, necessitates a selection strategy to increase the milk speed with no repercussion on the genetic merit of the milk yield [32,33]. However, heat stress can negatively affect these milking parameters. In the 4th zone of evaluation, the original level was not reached, which is again related to the reactions of cattle to the heat [26,27].

\section{Conclusions}

Despite the fact that the dairy cows on our farms had the same feed ration, plenty of drinking water and the same standard of animal welfare all the time, we can conclude that a reduced milk yield, increased average milk speed and increased maximum milk speed are related to THI. The results showed that at a THI value higher than 72 , the daily milk yield was negatively affected. A higher average milk speed as well as a higher maximum milk speed may occur at a THI value higher than 68 . It was found that the day after the decrease of the THI value under 68 , all of the monitored parameters improved. However, these parameters did not reach the original levels, which were before the effect of the THI. From these results it can be concluded that the effect of heat stress lasts significantly longer in dairy cows, even if the temperature-humidity conditions return to optimal values.

Author Contributions: Conceptualization, G.L. and I.K.; methodology, G.L. and I.K.; software, G.L. and Š.B.; validation, R.G., Š.B. and I.K.; formal analysis, G.L. and I.K.; investigation, Š.B. and P.K.; resources, P.K.; data curation, Š.B. and P.K.; writing-original draft preparation, G.L. and Š.B.; writing-review and editing, G.L. and I.K.; visualization, G.L., Š.B. and I.K..; supervision, R.G., Š.B. and I.K.; project administration, R.G.; funding acquisition, R.G. All authors have read and agreed to the published version of the manuscript.

Funding: This publication was supported by the Operational Programme Integrated Infrastructure within the project: Sustainable smart farming systems taking into account the future challenges 313011W112, co-financed by the European Regional development fund.

Institutional Review Board Statement: Not applicable.

Data Availability Statement: The datasets generated during and analysed during this study are not publicly available, but are available from the corresponding author on a reasonable request.

Acknowledgments: This publication was supported by the Operational Programme Integrated Infrastructure within the project: Sustainable smart farming systems taking into account the future challenges 313011W112, co-financed by the European Regional development fund.

Conflicts of Interest: The authors declare no conflict of interest.

\section{References}

1. Williams, D. Welfare Implications for Dairy Cattle of Modern Technological Advances: (I) Robotic Milking. J. Dairy Vet. Sci. 2019, 9, 1-4. [CrossRef]

2. Svennersten-Sjaunja, K.M.; Pettersson, G. Pros and cons of automatic milking in Europe. J. Anim. Sci. 2008, 86, 37-46. [CrossRef]

3. de Koning, C.J.A.M. Milking Machines I Robotic Milking. In Encyclopedia of Dairy Sciences, 2nd ed.; Fuquay, J.W., Ed.; Academic Press: Cambridge, MA, USA, 2011; pp. 952-958.

4. Bovo, M.; Agrusti, M.; Benni, S.; Torreggiani, D.; Tassinari, P. Random Forest Modelling of Milk Yield of Dairy Cows under Heat Stress Conditions. Animals 2021, 11, 1305. [CrossRef] [PubMed]

5. Speroni, M.; Pirlo, G.; Lolli, S. Effect of Automatic Milking Systems on Milk Yield in a Hot Environment. J. Dairy Sci. 2006, 89, 4687-4693. [CrossRef]

6. Bava, L.; Tamburini, A.; Penati, C.; Riva, E.; Mattachini, G.; Provolo, G.; Sandrucci, A. Effects of feeding frequency and environmental conditions on dry matter intake, milk yield and behaviour of dairy cows milked in conventional or automatic milking systems. Ital. J. Anim. Sci. 2012, 11, 230-235. [CrossRef] 
7. Schütz, K.; Rogers, A.R.; Cox, N.R.; Tucker, C.B. Dairy cows prefer shade that offers greater protection against solar radiation in summer: Shade use, behaviour, and body temperature. Appl. Anim. Behav. Sci. 2009, 116, 28-34. [CrossRef]

8. Dahl, G.E.; Tao, S.; Monteiro, A.P.A. Effects of late-gestation heat stress on immunity and performance of calves. J. Dairy Sci. 2016, 99, 3193-3198. [CrossRef]

9. Herbut, P.; Angrecka, S.; Walczak, J. Environmental parameters to assessing of heat stress in dairy cattle-A review. Int. J. Biometeorol. 2018, 62, 2089-2097. [CrossRef]

10. Sejian, V.; Bhatta, R.; Gaughan, J.; Dunshea, F.R.; Lacetera, N. Review: Adaptation of animals to heat stress. Animals 2018, 12, s431-s444. [CrossRef]

11. Saha, S.; Amalfitano, N.; Sturaro, E.; Schiavon, S.; Tagliapietra, F.; Bittante, G.; Carafa, I.; Franciosi, E.; Gallo, L. Effects of Summer Transhumance of Dairy Cows to Alpine Pastures on Body Condition, Milk Yield and Composition, and Cheese Making Efficiency. Animals 2019, 9, 192. [CrossRef]

12. Gantner, V.; Bobic, T.; Gantner, R.; Gregic, M.; Kuterovac, K.; Novakovic, J.; Potocnik, K. Differences in response to heat stress due to production level and breed of dairy cows. Int. J. Biometeorol. 2017, 61, 1675-1685. [CrossRef] [PubMed]

13. Lendelová, J.; Karandušovská, I.; Žitňák, M.; Bod'o, ̌̌.; Mihina, Š. Effect of Climatic Conditions on Differences in Thermo-Technical Properties of Organic Bedding in Laboratory Testing. Acta Technol. Agric. 2017, 20, 1-6. [CrossRef]

14. Habeeb, A.A.; Gad, A.E.; Atta, M.A. Temperature-Humidity Indices as Indicators to Heat Stress of Climatic Conditions with Relation to Production and Reproduction of Farm Animals. Int. J. Biotechnol. Recent Adv. 2018, 1, 35-50. [CrossRef]

15. Peng, D.; Chen, S.; Li, G.; Chen, J.; Wang, J.; Gu, X. Infrared thermography measured body surface temperature and its relationship with rectal temperature in dairy cows under different temperature-humidity indexes. Int. J. Biometeorol. 2019, 63, 327-336. [CrossRef] [PubMed]

16. Némethová, M.; Lendelová, J.; Šranková, V.; Žitňák, M.; Botto, L'. Verification of Thermo-Technical Characteristics of Selected Floor Constructions for Dairy Cows (Pilot Study). Acta Technol. Agric. 2020, 23, 87-91. [CrossRef]

17. Broucek, J.; Ryba, S.; Dianova, M.; Uhrinčat', M.; Soch, M.; Sistkova, M.; Mala, G.; Novak, P. Effect of evaporative cooling and altitude on dairy cows milk efficiency in lowlands. Int. J. Biometeorol. 2019, 64, 433-444. [CrossRef] [PubMed]

18. West, J.W. Effects of Heat-Stress on Production in Dairy Cattle. J. Dairy Sci. 2003, 86, 2131-2144. [CrossRef]

19. Spiers, D.; Spain, J.; Sampson, J.; Rhoads, R. Use of physiological parameters to predict milk yield and feed intake in heat-stressed dairy cows. J. Therm. Biol. 2004, 29, 759-764. [CrossRef]

20. Linvill, D.; Pardue, F. Heat Stress and Milk Production in the South Carolina Coastal Plains. J. Dairy Sci. 1992, 75, $2598-2604$. [CrossRef]

21. Bernabucci, U.; Biffani, S.; Buggiotti, L.; Vitali, A.; Lacetera, N.; Nardone, A. The effects of heat stress in Italian Holstein dairy cattle. J. Dairy Sci. 2014, 97, 471-486. [CrossRef]

22. Bouraoui, R.; Lahmar, M.; Majdoub, A.; Djemali, M.; Belyea, R. The relationship of temperature-humidity index with milk production of dairy cows in a Mediterranean climate. Anim. Res. 2002, 51, 479-491. [CrossRef]

23. Collier, R.J.; Dahl, G.E.; VanBaale, M.J. Major Advances Associated with Environmental Effects on Dairy Cattle. J. Dairy Sci. 2006, 89, 1244-1253. [CrossRef]

24. Zimbelman, R.B.; Rhoads, R.P.; Rhoads, M.L.; Duff, G.C.; Baumgard, L.H.; Collier, R.J. A Re-evaluation of the Impact of Temperature Humidity Index (THI) and Black Globe Humidity Index (BGHI) on Milk Production in High Producing Dairy Cows In Proceedings of the 24th Annual Southwest Nutrition and Management Conference, Tempe, AR, USA, 26-27 February 2009.

25. Bilby, T. How Do I Determine?: How Do I Calculate Temperature-Humidity Index (THI)? 2014. Available online: https:/ /www. progressivedairy.com/topics/herd-health/how-do-i-determine-how-do-i-calculate-temperature-humidity-index-thi (accessed on 7 July 2021).

26. Collier, R.J.; Hall, L.W.; Rungruang, S.; Zimbleman, R.B. Quantifying Heat Stress and Its Impact on Metabolism and Performance. In Proceedings of the Florida Ruminant Nutrition Symp, Gainesville, FL, USA, 31 January-1 February 2012. Available online: https: / www.google.com/url?sa=t\&rct=j\&q=\&esrc=s\&source=web\&cd=\&cad=rja\&uact=8\&ved=2ahUKEwjil77M9 _DzAhXSs6QKHfKzA9sQFnoECAIQAQ\&url=https\%3A\%2F\%2Fanimal.ifas.ufl.edu\%2Fapps\%2Fdairymedia\%2Frns\%2F201 2\%2F6CollierRNS2012a.pdf\&usg=AOvVaw1tr4Z0mPusrXYaCB543_iu (accessed on 7 July 2021).

27. Silanikove, N. Effects of heat stress on the welfare of extensively managed domestic ruminants. Livest. Prod. Sci. 2000, 67, 1-18. [CrossRef]

28. Kadzere, C.; Murphy, M.; Silanikove, N.; Maltz, E. Heat stress in lactating dairy cows: A review. Livest. Prod. Sci. 2002, 77, 59-91. [CrossRef]

29. Collier, R.J.; Eley, R.M.; Sharma, A.K.; Pereira, R.M.; Buffington, D.E. Shade Management in Subtropical Environment for Milk Yield and Composition in Holstein and Jersey Cows. J. Dairy Sci. 1981, 64, 844-849. [CrossRef]

30. Purwanto, B.P.; Abo, Y.; Sakamoto, R.; Furumoto, F.; Yamamoto, S. Diurnal patterns of heat production and heart rate under thermoneutral conditions in Holstein Friesian cows differing in milk production. J. Agric. Sci. 1990, 114, 139-142. [CrossRef]

31. Berman, A. Estimates of heat stress relief needs for Holstein dairy cows. J. Anim. Sci. 2005, 83, 1377-1384. [CrossRef]

32. Berry, D.; Coughlan, B.; Enright, B.; Burke, M. Factors associated with milking characteristics in dairy cows. J. Dairy Sci. 2013, 96, 5943-5953. [CrossRef] [PubMed]

33. Berry, D.P.; Coyne, J.; Coughlan, B.; Burke, M.; McCarthy, J.; Enright, B.; Cromie, A.R.; McParland, S. Genetics of milking characteristics in dairy cows. Animal 2013, 7, 1750-1758. [CrossRef] 